\title{
16．頭頸部悪性腫瘍に対する BRM（SPG）併用療法の
}

\author{
免疫学的パラメータに及ぼす影響 \\ 岡田卓也・吉田知之・佐伯哲郎・大塚幸之・青山由美子・奥平唯雄 \\ 舩坂宗太郎（東医大）
}

\begin{abstract}
頭頸部癌治療における BRM 投与の意義を明らかに するため, Natural Killer (NK) 活性, OKT 4, OKT 8, 及び末梢血リンパ球サブセットを SPG 投与群と非 投与群に分けて測定し，それらの変動を検討した。対 象は東京医科大学病院耳鼻咽喉科にて一次治療を行っ た頭頸部癌患者34例である.SPGの投与は，原則とし て $20 \mathrm{mg} \times 2$ 回/週,ただし外来通院時は $40 \mathrm{mg}+1$ 回/ 週とした. NK 活性は SPG 群, 対照群共に治療後やや 低下したが，SPG 群においては回復傾向が明らかで， 治療後 1 力月, 治療後 3 力月で治療前值以上に上昇し, 対照群と比べても有意な上昇を示した. $\mathrm{CD} 8^{+} \mathrm{CD} 11^{+}$ は, SPG 群で治療後有意に上昇し, 対照群では逆に低 下し両群間で有意差がみられた。この分画にはサプレ ッサー T 細胞の CD 8+ CD 11+ 群と NKサブセット の $\mathrm{CD} 8^{+} \mathrm{CD} 11^{+}$が含まれるが, $\mathrm{CD} 8^{++} \mathrm{CD} 11^{+}$では 両群で差はみられなかった。 CD 8+ CD 11-について は, 細胞\%は, SPG 群で治療後全時点で治療前值に比 べ上昇したが対照群では上昇傾向を示すものの治療後 3 カ月では前值にもどった。しかし, 両群間に有意差 はみられなかった.SPG 群の細胞数は対照群に比べ, 治療後 3 力月で有意に上昇した。 Leu $7^{+} \mathrm{CD} 16^{+}$につ いては，細胞\%はSPG 群と対照群とで差がなく，また 細胞数でも 1 力月， 3 力月で差はみられなかった. Leu 7-CD $16^{+} も$, 細胞\%・細胞数とも両群間で差はなか
\end{abstract}

った.リンパ球数は, SPG 群において低下の度合いが 軽度で, 早期回復傾向が認められた. PHA 刺激リンパ 球幼若化率は, 両群共に一過性に低下したが, SPG 群 では早期に回復する傾向がみられ, 治療後 1 力月の時 点で有意差がみられた. SCC は，両群間で差はみられ なかった、IAPは，SPG 群では低下傾向が明らかで， 対照群と比べ治療後 1 力月で有意差がみられた. IAP は生体の $\mathrm{M} \phi$ 由来の免疫抑制因子であり，SPG 投与 により IAPが低下したことは，SPGがM申の免废謂 節作用を高的ている可能性が示唆された。

まとめ 1. NK 活性は，SPG群において対照群よ り早期回復傾向がみられた．2. リンパ球数は，SPG 群に扔いて低下の度合いが軽度で早期回復傾向が認め られた。3．CD 8 陽性細胞は SPG 群で上昇傾向がみら れ, two color 解析でみると $\mathrm{CD} 8^{+} \mathrm{CD} 11^{+}$群が有意 に上昇しているが，CD $8^{++} \mathrm{CD} 11^{+}$群及びCD $8^{+}$

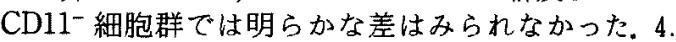
IAPはSPG 群において治療後有意に抑制された。 5 . PHA 刺激リンパ球幼若化率は，一過性に低下するも ののSPG 群において早期回復傾向がみられた。これ らのことから，頭頸部悪性腫場患者に対する SPG 投 与は手術, 放射線, 化学療法による免疫能の低下を早 期に回復することが示唆された。

\section{7. 頭頸部癌に対する rIL-2 局所投与の免疫組織学的検討}

\section{斉藤匡人・與田順一・木村貴昭・田端敏秀（和医大）}

はじめに 現在, rIL-2による癌免疫療法は rIL-2 直接単独投与, in vitro で誘導した LAK 細胞を中心と した盖子兔疫療法の両面に扔いて各科領域で施行され ている. 当教室でも頭頸部癌に対し集学的治療の一環 として rIL-2の局所投与を試みてきた。 今回我々は rIL-2 局所投与の有用性を検討する目的で投与前後の 癌組織におけるリンパ球浸潤とそのサブセットをモ， クローナル抗体を用いて兔疫組織学的に検討した。

対象と方法 対象は口腔, 口唇癌 12 例, 上顎癌 3 例, 中咽頭癌 1 例の計16例である. 1 日2000単位の TGP3 を腫湯周囲に局所注射および浅側頭動脈から持続動 注した。方法は rIL-2 投与前後で生検し,一部は $\mathrm{HE}$ 染色し，一部はモノクローナル抗体を使用し, Avidin Biotin Peroxidase Compley (ABC) 法にて免疫組織 染色を行った。

結果 16 例中, 口唇癌 2 例と舌癌 1 例に $\mathrm{CR}$, 口腔底
癌 1 例に PR が得られた. rIL-2 投与前後の組織像を HE 染色にて観察すると腫場周囲及び間質を中心にり ンパ球を主体とした練胞浸潤が見られ，治療効果とり ン八゚球浸潤の程度を見ると CR の 3 例と PR の 1 例で は投与後のリンパ球浸潤は著明に增加しているのに比 べ, PDの 2 例では投与後も投与前と変わらずリンパ 球浸潤は軽度であった。次に11例において腫湯浸潤り ンパ球のサブセットを検索した。腫崵浸潤リンパ球の 主体は Leu-4 ${ }^{+}$細胞の T リンパ球であり, rIL-2 局注 後増加し特に効果のあった症例では顕著であった。 Leu- $2 \mathrm{a}^{+}$細胞, Leu-3a $+3 \mathrm{~b}^{+}$細胞は Leu- $4^{+}$細胞より 軽度であるが，ほほ同程度に浸潤し，有効例では投与 後には増加していた. Leu-2a+ -15-の Cytotoxic T Lymphocyte (CTL) の性格を持 った細胞が主に浸潤している症例が多かった，NK細 胞を表す Leu-11b+ 練胞は投与前ではほとんど見られ 
なかったが rIL-2 投与後腫瘍間質に散在性に見られる 症例が認められた。 また活性化 T リンパ球を表す IL2 receptor ${ }^{+}$細胞は投与前にも少数例認めたが，rIL-2 投与後注とんどの症例で認められるようになった。

考案 最近, 腫瘍浸潤リンバ球 Tumor Infiltrating
Lymphocyte (TIL) を取りだしin vitroで活性化して もどす養子免疫療法が注目を浴びているが, rIL-2の 局所投与は in vivo でTIL を活性化させることのでき る合理的な治療法であると考えられた。

\section{OK-432 とCyclophosphamide を用いた術前免疫化学療法の検討}

\section{山道 至（近江八幡市民）石橋治昭（滋賀医大第 1 外科）}

目的 担癌宿主では手術等の影響により術後の免疫 能は一層低下し，このことが転移及び再発を促進する ものと考竞られている。この免疫能の低下を防止する 目的て術前に OK-432 と cyclophosphamide (CPA) を使用した免疫化学療法を行った。 CPA は suppressor $\mathrm{T}$ cell を抑制すると報告されているので OK-432 との併用によってより免疫能を高めうるものと考えら れた。 OK-432では皮内投与法と消化器外科領域等で 行われている経口投与法も行った。

方法 OK-432（皮内投与）+CPA（静注投与）(A 群)，OK-432 (経口投与) +CPA (静注投与) (B 群), 無投与群 (C 群) に分けた。 OK-432 は術前 2 週より投 与し $\mathrm{A}$ 群は $1 \mathrm{KE} よ り$ 始め漸次増量し合計 $26 \mathrm{KE}$ を皮 内投与し, CPA $(300 \mathrm{mg})$ は術 1 週間前に 1 回静注し た，B群は OK-432を術 2 週間前より $5 \mathrm{KE}$ を内服し 合計 $25 \mathrm{KE}$ 投与し, CPA (300mg) は術 1 週間前に 1 回静注した。対象症例は昭和60年 4 月から昭和 63 年 8 月末までの除外, 脱落例を除く, 甲状腺癌58症例であ った. 免疫能検査として白血球数,リンパ球数, SU-PS 皮内反応，PPD 皮内反応を測定した。末梢血のリンパ 球サブセットはレーザーフローサイトメトリー法（オ ルソ社製)にて測定した，その内容は OKT 3, OKT 4, OKT 8, Leu-11a, 4/8 比, Leu 2+/Leu 15-(Tc), Leu $2+/$ Leu $15+$ (Ts), Leu-7-/LYu 11c-(NKH) であり，それぞれの結果をパーセントで示した。また
術中所属りンパ節と所属外りンパ節をそれぞれ採取 し, 半切後一方は転移の有無の検索に供し, 残りは eagle RPMI 液にてサスペンションを作製し，末梢血 と同様にレーザーフローサイトメトリー法にてリンパ 球サブセットを测定した。

結果 SU-PS 皮内反応, PPD 皮内反応では A, B 両 群とも2 週間前と直前では有意に增強した（ $\mathrm{P}<0.05$, $\mathrm{P}<0.01)$. 末血のリンパ球サブセットの動きは $(-2 \mathrm{w}$, 直前) A，B雨群で OKT 8, Tsが有意に低下した $(\mathrm{P}<$ $0.05, \mathrm{P}<0.05)$. B 群では OKT 4 が有意に增加した $(\mathrm{P}<0.05)$. Leu-11a, NK H は特に各群で変わらなか つた。リンパ節のリンパ球サブセットで, 所属リンパ 節では転移 $(+)$ ならC群では転移 (一) に比較する とOKT 3, OKT 4 の减少傾向, OKT 8 0上昇, 4/8 比の低下が特に強く認められた。所属外リンパ節では 所属りンパ節転移 $(+),(一)$ 関係なく，A，B両群 の OKT 8，TsがC 群に比べ低下した $(\mathrm{P}<0.05 ， \mathrm{P}<$ 0.05). Leu-11a は A, B 耐群では所属りンパ節転移 $(+)$ 例は $($ - $)$ 例に比心゙有意に上昇した $(\mathrm{P}<0.05$, $\mathrm{P}<0.05$ ).

結論 甲状腺癌では $\mathrm{OK}-432$ と CPA を用いた免疫 化学療法で末梢血及びリンパ節の細胞性免疫能の増強 が示唆された. 更に OK-432の内服投与も皮内投与と 同様に免疫パフメータ一は甲状腺癌症例には有利な方 向に変動した。

\section{9. 頭頸部癌に対する動注化学養子免疫療法}

\section{江浦正郎・村上公輝・福田功一 - 山崎}

昨年の本学会で報告した経動脈的盖子免疫療法に, 今回は BRM 及び動注化学療法を組み合わせてその臨 床効果を観察したので報告した。

対象症例は歯肉癌 1 例 (T2N0M0, 上顎癌 3 例 (T3N0M0 1例, T4N0M0 2 例) で, 組織型は 1 例が 末分化癌他の 3 例は扁平上皮癌であった，治療計画は BRM の 1 つであるOK-432をまず投与開始し，次に 生検及び浅側頭動脈からのカテーテル留置を行う. Haemonetics V50 を用いて Leukapheresis を行い自

\section{滋・吹上忠祐・猪川勉・石川哮（熊大）}

己の末梢血単核細胞を得る。この末梢血単核細胞とマ イトマイシン $\mathrm{C}$ 処理した上顎扁平上皮癌株あるいは 自己癌細胞 (未分化癌の症例に使用) $100: 10$ 割合で 3 日間混合培善し,さらに recombinant interleukin 2 (rIL-2) $2 \mathrm{U} / \mathrm{ml}$ で培着し, killer 細胞を誘導する。こ の培養期間中に動注化学療法つまり CDDP 30 $\sim 50 \mathrm{mg} / \mathrm{m}^{2}$, つついて Pepleo $5 \mathrm{mg} /$ 日を 5 日間動注す る。これが終了して 2 日目に suppressor cell を抑制す る目的で cyclophosphamide $100 \mathrm{mg}$ を投与, 続いて 